\title{
Protecting US biotech firms
}

\section{Washington}

Two bills have been introduced into Congress that are intended to reform US patent and trade law and protect the US biotechnology industry against unfair foreign competition. The proposed legislation would bring US patent law in line with that of Japanese and Western European nations, and afford US inventors the same proprietary protection enjoyed by their foreign competitors.

The two nearly identical bills, introduced by Dennis DeConcini (Democrat, Arizona) in the Senate and Rick Boucher (Democrat, Virginia) in the House of Representatives, would remedy the confusion caused by a 1985 court decision, which severely restricts the ability of the US Patent and Trademark Office to award US biotechnology companies with process patent protection. If enacted, the legislation would overturn the earlier court ruling and provide the patent office with the authority to issue process patents as long as the starting materials are "novel".

The proposed legislation would "provide a simple solution to a complex area of law", DeConcini says.

Current US patent law works against biotechnology companies because it denies a patent on anything that is not "novel" or that is considered "obvious" in light of existing knowledge and techniques. Given these requirements for patentability, most biotechnology products fail the test.

The problem arises because biotechnology, unlike the traditional pharmaceutical industry, is not producing anything new.

Biotechnology involves the use of a known process - recombinant DNA technology to produce a genetically engineered version of a naturally occurring protein or enzyme. Although biotechnology is often the only means of producing practical quantities of a given material, product patents on a recombinant version are routinely denied by the patent office on the grounds of lack of novelty.

Compounding the problem is a 1985 federal circuit court decision, In re Durden, which has made it increasingly difficult for biotechnology companies to obtain process patent protection for biotechnology inventions. In that case, the court held that process patents could not be issued for processes that use novel starting materials - which are patentable in their own right - in combination with a known chemical process. Although the Durden case was itself not directly related to biotechnology, the patent office has taken the case into account when making its rulings on biotechnology process patents.

Supporters of the proposed legislation argue that many of the patent problems for biotechnology stem from what they see as an erroneous and inconsistent application by the patent office of the Durden decision.
Without the benefits of process patent protection, domestic companies are unable to prevent foreign companies from exploiting a legal loophole that exists in US patent and trade laws. According to those laws, if a product made by a patented process is manufactured offshore and imported, it constitutes infringement, but if there is no process patent involved, there are no restrictions on the importation of the products even if they were made with a starting technology, such as a gene or host cell, that is patented in the United States.

As long as biotech companies have a difficult time obtaining process patents, they will be vulnerable to unfair trade practices, say the bill's sponsors.

Proponents of the bill argue that a special case should be made for the biotechnology industry. The scale of investment in both time and money involved in bringing a new biopharmaceutical product to market, which typically takes 10 years and costs between \$100 and \$200 million, "stands in stark contrast to the ease at which the product can be copied", says Henri A. Termeer, president and chief executive officer of Genzyme Corporation.

The bill has bipartisan backing within Congress and the support of the Administration. It has also been endorsed by the major trade associations representing the biotechnology industry and has garnered wide support among universities. Although Durden rejections can sometimes be overcome, the bill's sponsors believe that smaller biotechnology companies and universities often forfeit process patent protection because they lack the financial resources to challenge the patent examiner's decision.

Opponents of the bill caution against congressional intervention at this time, particularly as the corrective legislation would apply to all technologies and not just biotechnology.

Given that biotechnology is still a young industry, the law in this area should be allowed "to mature through court decisions based on thoroughly presented factual situations without premature legislative action", says William F. Marsh, speaking on behalf of the Intellectual Property Owners Inc., a nonprofit association representing patent owners among the technology-based industries.

Marsh argues that as the bill would require the patent office to issue process claims without examination for novelty and nonobviousness, it would have a "destabilizing influence" on the US patent system. Far from clarifying the problems that have arisen from following the precedent of the Durden case, enactment of the legislation would lead to "great uncertainty as to the validity and scope of the process claims after the patent is issued", Marsh says.

Diane Gershon

\section{Cranky computer}

\section{London}

Wrrt a turn of a handle last week, a threetonne mechanical computer designed almost a century and half ago correctly cranked through its first public calculation: $0+0=0$. Known as the Difference Engine No. 2, the computer has been constructed by the London Science Museum to answer the question of whether Charles Babbage could have gone ahead and built the world's first computer after he designed it in 1849. As far as adding zeros go, Babbage seems vindicated.

But more challenging calculations still trip up the gear-driven behemoth. Two times two sometimes comes out one hundred trillion and four, a problem museum computer curator Doren Swade attributes to a faulty mechanism that carries "ones" to the next higher decimal place after addi-

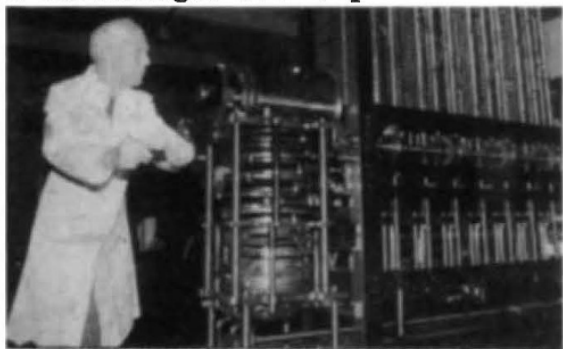

Number 2: hand-cranked, so-far inaccurate. tion overflows. Of the 210 such mechanisms in the steel and bronze machine, "we've got a few rogue carries," he said.

In private testing, the difference engine correctly calculates a table of numbers raised to the power of seven most of the time. But that is still not good enough; the machine is destined to be the top attraction of a history of computing exhibition at the science museum, and to settle the Babbage dispute. Engineers on the $£ 300,000$ project are now trying to get the machine running well enough for reliable calculations. But the machine was not designed for easy adjustment and Swade says it is possible that it may never reach full operation.

C.A.

ZOOEXCHANGE

\section{Kuwaiti home-from-home} London

IF the London zoo, facing a $£ 2$ million shortfall, is forced to make good its threat to close down this autumn, it will find at last one eager taker for its animals. Moussa al Khasti, director of the Kuwait zoo, which was ransacked during the Iraqi occupation, last week offered to take the London collection to replace his own animals, some of which were eaten by Iraqi troops. Only the Kuwait zoo's elands and buffaloes appear to have actually been eaten by the Iraqis, al Khasti says, but hundreds of birds, dozens of mammals and all 40 reptiles save three tortoises were either released or killed during the conflict. C.A. 